\title{
Respon pertumbuhan dan produksi bawang merah (Allium ascalonicum L.) terhadap frekuensi dan level mikroorganisme lokal bonggol pisang
}

\author{
(Growth response and production of shallot to application frequency and level of local \\ microorganism from banana stem) \\ Lestari, Sumarsono, dan Sutarno \\ Agroecotechnology, Faculty of Animal and Agricultural Sciences, \\ Diponegoro University \\ Tembalang Campus, Semarang 50275 - Indonesia \\ Corresponding E-mail:succilestari98@gmail.com
}

\begin{abstract}
This study aimed to examine the effect of level and frequency of local microorganism (MOL) from banana stem on the growth and production of shallots. The study took place in February - April 2018. The study was carried out in a greenhouse of the Food Crops and Horticulture Protection Center (BPTPH), and the Plant Ecology and Production Laboratory, Faculty of Animal and Agricultural Sciences, Diponegoro University, Semarang. The study used Factorial 5 x 3 Complete Randomized Design (CRD) with 3 replications. The first factor was the level of local microorganism $(0,10,20,30$ and $40 \mathrm{ml}$ ). The second factor was the frequency of watering (1 week, 2 weeks, 3 weeks). The parameters of the study were plant height, number of leaves, fresh weight of vegetative plants, number of shallot bulbs. Giving a $40 \mathrm{ml}$ local microorganism level resulted in growth in plant height, vegetative fresh weight and number of shallot bulbs.
\end{abstract}

Keywords: shallot, local microorganism, level, frequency

\begin{abstract}
ABSTRAK
Penelitian ini bertujuan untuk mengkaji pengaruh level MOL bonggol pisang yang sesuai, pengaruh frekuensi serta mengetahui kombinasi level dan frekuensi terhadap pertumbuhan dan produksi bawang merah. Penelitian berlangsung pada bulan Februari - April 2018. Penelitian dilakuan di rumah kaca Balai Perlindungan Tanaman Pangan dan Hortikultura (BPTPH), dilanjutkan dengan menimbang berat basah di Laboratorium Ekologi dan Produksi Tanaman, Fakultas Peternakan dan Pertanian Universitas Diponegoro, Semarang. Rancangan yang digunakan dalam penelitian adalah Percobaan Faktorial 5 x 3 Rancangan Acak Lengkap (RAL) dengan ulangan 3 kali. Faktor pertama adalah level mol $(0,10,20,30$ dan $40 \mathrm{ml}$ ) Faktor kedua frekuensi penyiraman (1 minggu, 2 minggu, 3 minggu). Parameter penelitian yaitu Tinggi tanaman, jumlah daun, bobot segar vegetatif tanaman, jumlah umbi bawang merah. Pemberian level mol $40 \mathrm{ml}$ menghasilkan pertumbuhan tinggi tanaman, bobot segar vegetatif tanaman dan jumlah umbi bawang merah,
\end{abstract}

Kata Kunci : Bawang Merah, Mol, Level dan frekuensi

\section{PENDAHULUAN}

Bawang merupakan sayuran rempah yang meskipun bukan asli berasal dari Indonesia, tetapi dalam pemanfaatannya sebagai bumbu pelezat di setiap masakan sungguh lekat dengan lidah masyarakat Indonesia (Wibowo, 2009). Tanaman bawang merah di Indonesia menjadi salah satu tanaman yang diusahakan oleh kebanyakan para petani dalam menjalankan roda perekonomian. Meskipun banyak petani yang membudidayakan bawang merah, namun belum dapat menutupi 
jumlah permintaan pasar untuk konsumsi dan untuk bibit, sehingga Indonesia harus melakuan impor untuk memenuhi kebutuhan tersebut (Sumarni dan Hidayat, 2005). Produksi bawang merah di Indonesia yang bersifat musiman menyebabkan ketersediaan di luar musim panen tidak dapat memenuhi tingkat kebutuhan pasar sehingga untuk memenuhinya perlu dilakukan tindakan impor.Pemerintah melakukan kegiatan impor yang bertujuan untuk menjaga ketersediaan bawang merah dan menjaga kestabilan harga pasar (Kementan, 2015). Peningkatan jumlah permintaan bawang merah yang tidak diikuti dengan peningkatan jumlah produksi nasional. (Badan Pusat Statistik, 2013) menyebutkan bahwa hasil produksi bawang merah di Indonesia pada tahun 2010-2013 mengalami penurunan sebesar $10 \%$ yaitu 1.048 .934 ton, 893.124 ton, 964.221 ton dan 958.595 ton.

Berkurangnya ketersediaan bawang merah yang hanya ada pada musim tertentu, juga disebabkan karena penerapan sistem budidaya, seperti jarak tanam dan pemupukan yang belum diterapkan secara intensif oleh petani. Ketersediaan unsur hara bagi masa pertumbuhan tanaman sangat diperlukan karena menjadi faktor utama dalam meningkatkan jumlah produksi serta memperbaiki sifat fisik dan kimia tanah (Siagian dkk., 2014). Menurut Dharma dkk. (2018) Mikroorganisme Lokal (MOL) adalah salah satu mikroorganisme yang dimanfaatkan sebagai starter yang membantu dalam pembuatan pupuk organik padat maupun cair. Bahan utama dalam membuat MOL terdiri dari beberapa komponen yang mengandung karbohidrat, glukosa dan sumber mikroorganisme.

Menurut Purwasasmita dan Kurnia (2009), pada MOL terkandung unsur hara makro dan mikro dan juga mengandung mikroba yang berpotensi untuk membantu proses perombak bahan organik, perangsang pertumbuhan dan sebagai agen pengendali hama dan penakit tanaman. Berdasarkan kandungan yang terdapat di dalam MOL tersebut, maka MOL dapat digunakan sebagai pendekomposer, pupuk hayati dan sebagai pestisida organik terutama sebagai fungisida. Pemberian larutan MOL yang terbuat dari rebung bambu memberikan hasil secara signifikan terhadap tinggi batang, berat basah dan berat kering pada tanaman sawi caisim (Yeremia 2016).
Pengaplikasian MOL dari bonggol pisang berpengaruh nyata terhadap tinggi tanaman kacang tanah 30 dan 45 HST, jumlah polong per rumpun, berat kering per pot dan produksi per hektar. Perlakuan MOL bonggol pisang ambon dapat meningkatkan hasil sebesar $22,98 \%$ bila dibandingkan dengan hasil terendah yang diperoleh pada perlakuan tanpa mol bonggol pisang (Juliandi dan Rosmaiti, 2016).

Konsentrasi MOL bonggol pisang yang paling baik adalah pada konsentrasi $3 \mathrm{ml} . \mathrm{l}^{-1}$ air karena merupakan konsentrasi paling rendah namun dapat mengurai bahan organik menjadi kompos dengan waktu yang sama dengan konsentrasi 4.ml. $\mathrm{l}^{-1}$ air dan $5 \mathrm{ml} . \mathrm{l}^{-1}$ air (Sidharta dkk., 2013). Pada perlakuan konsentrasi mol bonggol pisang sebanyak $100 \mathrm{ml} / 1$ dan dosis pupuk kandang kambing $6 \mathrm{~kg} /$ plot dengan lebar 1 $\mathrm{m}$ dan panjang $2 \mathrm{~m}$ dapat memberikan pengaruh yang nyata terhadap produksi perplot tanaman kedelai (Herlinawati dkk., 2017).

Tujuan dari penelitian ini adalah untuk mengkaji pengaruh level MOL bonggol pisang yang sesuai, pengaruh frekuensi serta mengetahui kombinasi level dan frekuensi terhadap pertumbuhan dan produksi bawang merah.

\section{MATERI DAN METODE}

Penelitian akan dilaksanakan dari bulan Februari s/d April 2018 di rumah kaca Balai Perlindungan Tanaman Pangan dan Hortikultura (BPTPH), dilanjutkan di Laboratorium Ekologi dan Produksi Tanaman, Fakultas Peternakan dan Pertanian Universitas Diponegoro, Semarang.

\section{Materi}

Penelitian ini menggunakan alat dan bahan umbi bawang merah varietas Bima, penyiapan lahan tanaman, tanah, pupuk organik, $1 \mathrm{~kg}$ bonggol pisang ambon, 2 ons gula merah yang lebih dulu dihaluskan/cairan tebu. 2 liter air kelapa. Alat yang digunakan antara lain yaitu ember, timbangan, penggaris, polybag ukuran 40x40 cm, cangkul, pisau, alat ukur dan thermometer untuk mengetahui suhu MOL.

\section{Metode}

Penelitian dilakukan dengan beberapa tahap. Tahap pertama yaitu pembuatan MOL yang 
menggunakan bonggol pisang ambon. Cara pembuatan MOL bonggol pisang :(a) bonggol pisang ambon $1 \mathrm{~kg}$ disiapkan (b) bonggol pisang selanjutnya dipotong menjadi kecil - kecil dan dihaluskan dengan blender dan dituang ke dalam ember. (c) 2 ons gula merah yang telah dihaluskan kemudian dicampurkan ke dalam ember (c) selanjutnya ditambahkan 2 liter air kelapa dan diaduk hingga rata (d) setelah semua bahan tercampur dengan rata kemudian ditutup dengan rapat dan disimpan selama 3 minggu. Pengukuran suhu dilakukan setiap pagi dengan menggunakan termometer.

Penyiapan bibit bawang merah dengan varietas bima. Penyiapan media tanam menggunakan polybag ukuran $40 \times 40 \mathrm{~cm}$ yang berisi media tanah $10 \mathrm{~kg}$ yang diberi pupuk organik sebanyak $10 \%$ atau $1 \mathrm{~kg}$.Penanaman dilakukan pada lubang tanam dengan kedalam \pm 2 $\mathrm{cm}$. Setiap polybag ditanami 3 umbi. Setelah 2 minggu penanaman umbi bawang merah, kemudian di pilih 1 bibit bawang merah yang dapat tumbuh dengan baik. Jarak antar polybag yaitu $30 \times 30 \mathrm{~cm}$. Pemberian MOL limbah bonggol pisang dengan cara disemprotkan pada media tanah dengan frekuensi penyiraman yaitu 1 minggu, 2 minggu setelah tanaman dan 3 minggu setelah tanam hingga umur tanaman mencapai 50 hari. Pemeliharaan pada tanaman seperti penyiraman, penyulaman, penyiangan dan perawatan. Pengukuran pertumbuhan tanaman dimulai setelah tanaman berumur 2 MST hingga 6 MST. Pemanenan dilakukan setelah 70 HST. Bobot segar dan kering pada hasil produksi bawang merah kemudian ditimbang. Parameter yang diamati dalam peneitian ini diantaranya yaitu : Tinggi tanaman, jumlah daun, berat segar vegetatif tanaman dan jumlah umbi bawang merah.

\section{Rancangan percobaan dan analisis data}

Penelitian dilaksanakan dengan percobaan faktorial 5 x 3 menggunakan Rancangan Acak Lengkap (RAL) yang terdiri dari 3 ulangan. Faktor yang pertama adalah level MOL yaitu P0 $=0 \mathrm{ml}$ (kontrol), $\mathrm{P} 1=(10 \mathrm{ml}), \mathrm{P} 2=(20 \mathrm{ml}), \mathrm{P} 3=$ $(30 \mathrm{ml}), \mathrm{P} 4=(40 \mathrm{ml})$ pada setiap polybag. Faktor kedua adalah frekuensi aplikasi bonggol pisang yaitu $\mathrm{T} 1=($ tiap 1 minggu setelah tanam $), \mathrm{T} 2=$ (tiap 2 minggu setelah tanam, T3 = (tiap 3 minggu setelah tanam). Data hasil pengamatan diolah dengan. analisis ragam untuk mengetahui pengaruh perlakuan, dilanjutkan dengan pembandingan nilai tengah dengan Duncan MultipleRange Test (DMRT) pada taraf $5 \%$ untuk mengetahui perbedaan antar perlakuan.

\section{HASIL DAN PEMBAHASAN}

\section{Tinggi Tanaman Bawang Merah}

Hasil analisis ragam menunjukkan bahwa tidak adanya pengaruh interaksi antara perlakuan frekuensi penyiraman dan level mol terhadap tinggi tanaman. Terdapat pengaruh nyata $(\mathrm{P}<0,05)$ pada perlakuan level mol terhadap tinggi tanaman, sedangkan pada frekuensi penyiraman tidak memberikan pengaruh nyata $(\mathrm{P}<0,05)$ terhadap tinggi tanaman bawang merah. Hasil uji DMRT tinggi tanaman di sajikan pada Tabel 1.

Hasil penelitian Tabel 1 menunjukkan bahwa

Tabel 1. Rerata pengamatan tinggi tanaman akibat level mol bonggol pisang dan frekuensi penyiraman

\begin{tabular}{|c|c|c|c|c|}
\hline \multirow{2}{*}{ Level Mol } & \multicolumn{3}{|c|}{ Frekuensi Penyiraman Mol (Bonggol Pisang) } & \multirow{2}{*}{ Rata-rata } \\
\hline & B1 (1minggu) & B2 (2minggu) & B3 (3minggu) & \\
\hline & 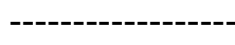 & (cm) & $\cdots$ & \\
\hline A0 (kontrol) & 33,17 & 36,00 & 34,33 & $34,50^{\mathrm{b}}$ \\
\hline A1 $(10 \mathrm{ml})$ & 37,67 & 33,17 & 32,83 & $34,56^{\mathrm{b}}$ \\
\hline A2 $(20 \mathrm{ml})$ & 42,67 & 38,83 & 36,83 & $39,44^{\mathrm{ab}}$ \\
\hline A3 $(30 \mathrm{ml})$ & 37,00 & 39,17 & 35,00 & $37,06^{\mathrm{ab}}$ \\
\hline A4 $(40 \mathrm{ml})$ & 42,83 & 42,33 & 36,33 & $40,50^{\mathrm{a}}$ \\
\hline Rata-rata & 38,67 & 37,90 & 35,07 & \\
\hline
\end{tabular}

Superskrip yang berbeda pada kolom yang sama menunjukkan perbedaan yang nyata $(p<0,05)$ 
di antara perlakuan level mol memberikan perbedaan nyata $(p<0,05)$ pada tinggi tanaman bawang merah. Perlakuan level A4 (40 ml) menunjukkan hasil tertinggi nyata $(\mathrm{p}<0,05)$ lebih besar dibandingkan A0 (kontrol) dan A1 $(10 \mathrm{ml})$ tetapi tidak berbeda dengan perlakuan A2 $(20 \mathrm{ml})$ dan A3 (30 ml). Hal ini diduga jumlah level mol yang diberikan cukup tinggi mampu mempercepat proses dekomposisi bahan organik di dalam tanah, tetapi tinggi tanaman bawang merah rata-rata hanya mencapai $32-42 \mathrm{~cm}$ dan belum termasuk karaktersitik dari tinggi tanaman bawang merah varietas Bima. Keadaan tersebut terjadi karena suhu lingkungan yang melebihi batas maksimal bagi perkembangan mikroba yang ada di ada di dalam mol, sehingga tidak dapat memenuhi kebutuhan nutrisi tanaman. Hal ini sesuai dengan pendapat Pitojo (2003) yang menyatakan bahwa varietas Bima memiliki karakterisitik tinggi tanaman berkisar antara 25-44 cm. Pertumbuhan tinggi tanaman salah satunya di pengaruhi oleh kondisi lingkungan tumbuh. Kondisi lingkungan yang optimum akan mendukung pertumbuhan vegetatif tanaman termasuk pada tinggi tanaman. Hal ini sesuai dengan pendapat Rostikawati dkk. (2012) yang menyatakan bahwa dengan pemberian cairan MOL akan meningkatkan kandungan mikroba di dalam tanah sehingga akan mempercepat proses mineralisasi sehingga dapat berjalan secara optimal keadaan tersebut akan meningakatkan kebutuhan unsur hara pada tanaman menjadi terpenuhi dengan baik. Hal ini didukung oleh pendapat Panudju (2011) yang menyatakan bahwa MOL berfungsi sebagai bahan utama dalama proses pengomposan bahan organik menjadi kompos.

Hasil penelitian Tabel 1 menunjukkan bahwa di antara perlakuan frekuensi penyiraman tidak berbeda nyata pada parameter tinggi tanaman. Hal ini diduga karena pada saat dilakukannya penelitian di dalam rumah kaca yang memiliki suhu yang rata-rata tinggi yaitu mencapai $43-53^{\circ}$ $\mathrm{C}$, kondisi suhu tersebut meningkat pada setiap minggunya sehingga mengakibatkan tingkat penguapan yang menjadikan proses penyerapan nutrisi yang terkandung dalam mol oleh tanaman tidak maksimal dikarenakan sinar matahari yang berlebih. Hal ini sesuai dengan pendapat Yani (2016) yang menyatakan bahwa suhu optimum bagi pertumbuhan mikroba Bacilllus sp. adalah dengan suhu $37^{\circ}$ C. Hal ini didukung oleh pendapat Waluyo (2004) yang menyatakan bahwa suhu merupakan salah satu aspek penting dalam kehidupan mikroba. Pada tanaman terdapat 3 suhu pertumbuhan diantarnya yaitu suhu optimum kondisi di mana kegiatan mikroba masih berlangsung, suhu maksimum adalah suhu yang tertinggi dimana kondisisi mikroba masih hidup, tetapi dengan tingkat kegiatan fisiologi yang rendah, sedangkan pada suhu yang optimum adalah suhu yang baik bagi pertumbuhan mikroba. Hal ini didukung oleh pendapat Hatta (2006) yang menyatakan bahwa suhu kardinal adalah suhu yang berada dari suhu minimum hingga suhu maksimum. Setiap spesies dan varietas tanaman mempunyai suhu kardilannya masing-masing, apabila tanaman berada pada kondisi di bawah suhu minimum dan di atas suhu maksimum akan mengakibatkan laju pertumbuhan tanaman menjadi rendah, sedangkan pada suhu optimum akan diperoleh laju pertumbuhan tanaman yang lebih tinggi.

\section{Jumlah Daun Bawang Merah}

Hasil analisis ragam menunjukkan bahwa tidak adanya pengaruh interaksi antara pemberian level mol dan frekuensi penyiraman terhadap jumlah daun. Pemberian level mol tidak memberikan pengaruh nyata $(\mathrm{p}<0,05)$ pada jumlah daun, begitu juga dengan frekuensi penyiraman tidak ada pengaruh nyata $(p<0,05)$ terhadap jumlah daun bawang merah. Hasil Uji DMRT jumlah daun disajikan pada Tabel 2.

Hasil penelitian Tabel 2 menunjukkan bahwa di antara perlakuan level mol tidak berbeda nyata pada jumlah daun bawang merah. Hal ini diduga pada saat fase vegetatif tanaman pemberian mol bonggol pisang tidak mencukupi kebutuhan nutrisi pertumbuhan bawang merah. Pemberian mol bonggol pisang pada level $40 \mathrm{ml}$ sudah termasuk kedalam level yang tinggi, akan tetapi mikroba yang terdapat di dalam mol tidak dapat mempercepat proses dekomposis bahan organik karena di pengaruhi oleh faktor lingkungan. Suhu yang sesuai bagi pertumbuhan mikroba yaitu $37^{\circ}$ $\mathrm{C}$, sedangkan suhu pada rumah kaca mencapai $53^{\circ}$ $\mathrm{C}$, sehingga tidak dapat mencukupi kebutuhan nutrisi tanaman, sebaliknya apabila kondisi lingkungan sudah sesuai dengan syarat pertumbuhan mikroba maka proses dekomposis 
Tabel 2.Rerata jumlah daun bawang akibat level mol bonggol pisang dan frekuensi penyiraman

\begin{tabular}{|c|c|c|c|c|}
\hline \multirow{2}{*}{ Level Mol } & \multicolumn{3}{|c|}{ Frekuensi Penyiraman Mol (Bonggol Pisang) } & \multirow{2}{*}{ Rata-rata } \\
\hline & $\mathrm{B} 1(1 \mathrm{minggu})$ & B2 (2 minggu) & B3 (3 minggu) & \\
\hline & \multicolumn{3}{|c|}{------------------------ helai -------------------------------- } & \\
\hline A0 (kontrol) & 11,00 & 14,33 & 14,00 & 13,11 \\
\hline $\mathrm{A} 1(10 \mathrm{ml})$ & 18,00 & 9,67 & 16,67 & 14,78 \\
\hline A2 $(20 \mathrm{ml})$ & 13,33 & 19,67 & 19,67 & 17,56 \\
\hline A3 (30 ml) & 15,67 & 13,33 & 19,67 & 16,22 \\
\hline A4 $(40 \mathrm{ml})$ & 24,33 & 18,00 & 13,67 & 18,67 \\
\hline Rata-rata & 16,47 & 15,00 & 16,73 & \\
\hline
\end{tabular}

bahan organik dapat berlangsung dengan baik. Hal ini sesuai dengan pendapat Suwandi dkk. (2012) yang menyatakan bahwa kebutuhan pupuk untuk produksi bawang merah bervariasi antara $150-300 \mathrm{~kg} / \mathrm{ha} \mathrm{N}, 90-180 \mathrm{~kg} / \mathrm{ha} \mathrm{P}$ dan $50-100 \mathrm{~kg} /$ ha $\mathrm{K}$. Hal ini didukung oleh pendapat Haq dkk. (2015) yang menyatakan bahwa kandungan unsur hara, terutama nitrogen dalam jumlah yang tinggi dapat meningkatkan pertumbuhan daun lebih banyak. Nitrogen merupakan salah satu unsur hara yang berperan penting dalam bagi pertumbuhan tanaman. Nitrogen berperan penting dalam menyusun protein yakni sebesar $16-18 \%$ protein yang tersusun oleh adanya nitrogen. Selain itu, zat pengatur tumbuh yang terdapat pada bawang merah berupa hormon pertumbahan yaitu hormon auksin tidak dapat bekerja dengan baik karena faktor lingkungan yang tidak sesuai bagi hormon auksin. Hal ini sesuai dengan pendapat Syfandy (2017) yang menyatakan bahwa kandungan hormon pada bawang merah berupa hormon auksin dan giberrelin untuk mempercepat proses pertumbuhan untuk menstimulasi pertumbuhan pada daun maupun pada batang. Hal ini sesuai dengan pendapat Neliyati (2007) yang menyatakan bahwa Zat Pengatur Tumbuh (ZPT) dapat bekerja dengan baik pada suhu lingkungan berkisar antara $22-28{ }^{\circ} \mathrm{C}$ dan kondisi kelembaban mencapai $>70 \%$.

Kelembaban udara yang rendah yang mencapai $65 \%$ cukup mempengaruhi pertumbuhan jumlah daun pada tanaman. Hal ini sesuai dengan pendapat Djumali dan Nurnasari (2010) yang menyatakan bahwa kelembaban udara dapat mempengaruhi pertumbuhan tanaman, karena dapat mempengaruhi proses fotosintesis. Kelembaban udara berpengaruh pada keseimbangan air dalam tanah dan tanaman. Jika kelembaban udara optimal, fotosintat akan mengalir ke bagian pucuk, sehingga meningkatkan produksi daun.

Hasil penelitian Tabel 2 menunjukkan bahwa di antara perlakuan frekuensi penyiraman tidak berbeda nyata pada parameter jumlah daun tanaman bawang merah. Semakin lama frekuensi penyiraman mol yang diberikan diduga menyebabkan jumlah unsur hara yang tersedia semakin sedikit. Pada masa vegetatif tanaman, kandungan unsur hara yang ada di dalam mol tidak mencukupi kebutuhan tanaman seperti halnya unsur hara N $0,04 \%$, P 0,51 \% dan K 0,6 $\%$ yang tidak sesuai dengan standar. Menurut Badan Standarisasi Nasional (2004) yang menyatakan bahwa standar mutu kandungan unsur hara makro dalam pupuk cair yaitu $\mathrm{N}, \mathrm{P}$ dan $\mathrm{K}$ mencapai 3-6 \%. Hal ini didukung oleh pendapat Parman (2007) yang menyatakan bahwa pada saat tanaman memasuki fase vegetatif, memerlukan sejumlah nutrisi untuk menunjang pertumbuhan. Oleh karena itu ketersediaan unsur hara seperti halnya $\mathrm{N}$ yang berperan dalam menigkatkan klorofil untuk mempercepat proses fotosintat. Hasil fotosintat tersebut akan digunakan tanaman dalam pembentukan daun.

\section{Berat Segar Vegetatif Tanaman}

Hasil analisis ragam menunjukkan bahwa tidak adanya pengaruh interaksi antara pemberian level mol dan frekuensi penyiraman terhadap berat segar vegetatif tanaman bawang merah. Terdapat 
pengaruh nyata $(\mathrm{P}<0,05)$ pada perlakuan pemberian level mol terhadap berat segar vegetatif tanaman bawang merah, tetapi pada perlakuan frekuensi penyiraman tidak memberikan pengaruh nyata terhadap berat segar vegetatif bawang tanaman merah. Hasil Uji DMRT Berat Segar Vegetatif Tanaman disajikan pada Tabel 3.
Hasil penelitian Tabel 3 menunjukkan bahwa di antara perlakuan frekuensi penyiraman tidak berbeda nyata pada berat segar vegetatif tanaman bawang merah. Hal ini diduga karena lamanya frekuensi penyiraman yang diberikan yaitu 1, 2 dan 3 minggu yang tidak dapat mencukupi kebutuhan unsur hara yang dibutuhkan

Tabel 3. Rerata berat segar vegetatif tanaman akibat level mol bonggol dan frekuensi penyiraman

\begin{tabular}{|c|c|c|c|c|}
\hline \multirow{2}{*}{ Level Mol } & \multicolumn{3}{|c|}{ Frekuensi Penyiraman Mol (Bonggol Pisang) } & \multirow[t]{2}{*}{ Rata-rata } \\
\hline & $\mathrm{B} 1(1$ minggu $)$ & B2 (2 minggu) & B3 (3 minggu) & \\
\hline A0 (kontrol) & 2.56 & 9.88 & 10.09 & $7.51^{\mathrm{c}}$ \\
\hline A1 $(10 \mathrm{ml})$ & 5,98 & 19,33 & 4,16 & $9,83^{\mathrm{bc}}$ \\
\hline $\mathrm{A} 2(20 \mathrm{ml})$ & 7,25 & 8,84 & 12,77 & $9,62^{\mathrm{b}}$ \\
\hline A3 $(30 \mathrm{ml})$ & 10,21 & 6,82 & 7,25 & $8,09^{\mathrm{b}}$ \\
\hline A4 $(40 \mathrm{ml})$ & 14,00 & 10,50 & 19,04 & $14,51^{\mathrm{a}}$ \\
\hline Rata-rata & 8,00 & 11,07 & 10,66 & \\
\hline
\end{tabular}

Superskrip yang berbeda pada kolom yang sama menunjukkan perbedaan yang nyata $(p<0,05)$

Hasil penelitian Tabel 3 menunjukkan bahwa di antara perlakuan level mol memberikan perbedaan nyata $(\mathrm{P}<0,05)$ berat segar vegetatif tanaman bawang merah. Perlakuan level A4 (40 $\mathrm{ml})$ menunjukkan hasil tertinggi nyata lebih besar dibandingkan dengan A2 $(20 \mathrm{ml})$ dan A3 $(30 \mathrm{ml})$ dan A0 (kontrol) dan A1 $(10 \mathrm{ml})$ berat vegetatif tanaman yang dihasilkan cenderung lebih sedikit. Berat segar bagian vegetatif tanaman dengan level mol $40 \mathrm{ml}$ yang rata-rata mencapai $14,51 \mathrm{~g}$ dan tergolong masih rendah, karena bagian vegetatif tanaman seperti halnya tinggi tanaman, jumlah daun yang di hasilkan belum sesuai dengan karaktersitik bawang merah varietas bima sehingga mempengaruhi berat segar vegetaif tanaman. Hal ini diduga karena pada saat terjadinya proses metabolisme tanaman seperti transpirasi, respirasi dan fotosintesis yang mempengaruhi jumlah daun dan tinggi tanaman terganggu akibat dari faktor lingkungan yaitu suhu dan kelembaban yang tidak sesuai bagi pertumbuhan bawang merah. Hal ini didukung oleh pendapat Yuliawan (2012) yang menyatakan bahwa suhu udara akan sangat mempengaruhi fase perkembangan tanaman sehingga mempengaruhi umur tanaman. Akibatnya biomassa serta hasil panen menjadi berkurang. pada setiap fase pertumbuhan tanaman, sehingga akar yang tumbuh sedikit yang mengakibatkan transfer unsur hara keseluruh bagian tanaman berkurang. Hal ini sesuai dengan penelitian Wuryandari (2015) yang menyatakan bahwa terdapat pengaruh frekuensi pada pemberian mikroorganisme lokal yang optimal bagi pertumbuhan dan hasil produksi tanaman tomat dengan frekuensi penyiraman 2 kali dalam seminggu.

\section{Jumlah Umbi Bawang merah}

Hasil analisis ragam menunjukkan bahwa tidak adanya pengaruh interaksi antara pemberian level mol dan frekuensi penyiraman terhadap jumlah umbi bawang merah. Terdapat pengaruh nyata pada $(\mathrm{P}<0,05)$ perlakuan pemberian level mol terhadap jumlah umbi bawang merah, tetapi pada perlakuan frekuensi penyiraman tidak memberikan pengaruh nyata terhadap jumlah umbi bawang merah. Hasil Uji DMRT jumlah umbi bawang merah pada Tabel 4.

Hasil penelitian Tabel 4 menunjukkan bahwa di antara perlakuan level mol memberikan perbedaan nyata $(p<0,05)$ terhadap jumlah umbi bawang merah. Perlakuan level A4 $(40 \mathrm{ml})$ menunjukkan hasil tertinggi nyata lebih besar 
Tabel 4. Rerata jumlah umbi bawang merah akibat level mol bonggol pisang dan frekuensi penyiraman

\begin{tabular}{|c|c|c|c|c|}
\hline \multirow{2}{*}{ Level Mol } & \multicolumn{3}{|c|}{ Frekuensi Penyiraman Mol (Bonggol Pisang) } & \multirow[t]{2}{*}{ Rata-rata } \\
\hline & B1 (1 minggu) & B2 (2 minggu) & B3 (3 minggu) & \\
\hline & ---- & ---buah-- & ----- & \\
\hline A0 (kontrol) & 6,33 & 5,67 & 6,67 & $6,22^{\mathrm{bc}}$ \\
\hline A1 $(10 \mathrm{ml})$ & 7,00 & 6,00 & 5,00 & $6,00^{\mathrm{c}}$ \\
\hline A2 $(20 \mathrm{ml})$ & 6,33 & 6,33 & 8,00 & $6,89^{\mathrm{ab}}$ \\
\hline A3 $(30 \mathrm{ml})$ & 8,33 & 5,67 & 10,00 & $8,00^{\mathrm{ab}}$ \\
\hline A4 $(40 \mathrm{ml})$ & 9,33 & 9,00 & 7,67 & $8,67^{\mathrm{a}}$ \\
\hline Rata-rata & 7,47 & 6,53 & 7,47 & \\
\hline
\end{tabular}

dibandingkan A0 (kontrol) dan A1 (10 ml) tetapi tidak berbeda dengan $\mathrm{A} 2(20 \mathrm{ml})$ dan A3 $(30 \mathrm{ml})$. Jumlah produksi bawang merah tersebut termasuk lebih rendah karena rata-rata hanya mencapai 2-4 ton/ha jika di bandingkan dengan jumlah produksi bawang merah varietas bima yang hingga mencapai 9,9 ton/ ha. Hal ini diduga karena proses pertumbuhan tanaman seperti halnya kegiatan respirasi, laju transpirasi dan fotosintesis tanaman terganggu akibat kondisi suhu yang tinggi dan kelembaban yang rendah, sehingga menurunkan hasil produksi tanaman. Faktor lingkungan sangat mempengaruhi kegiatan metabbolisme tanaman, apabila kondisi lingkungan tumbuh tanaman sudah sesuai nutrisi yang diberikan dapat diserap baik oleh tanaman. Hal ini sesuai dengan pendapat Setianingsih (2009) yang menyatakan bahwa pada mol bonggol pisang terdapat sejumlah kadar asam fenolat yang tinggi, asam tersebut membantu dalam pengikatan ion-ion $\mathrm{Al}, \mathrm{Fe}$ dan $\mathrm{Ca}$ sehingga keberadaanya dapat membantu ketersediaan unsur hara $\mathrm{P}$ pada tanah yang digunakan dalam proses pembugaan dan pembentukan buah. Hal ini didukung oleh pendapat Santosa (2008) yang menyatakan bahwa MOL mengandung unsur hara makro dan mikro sehigga dapat meningkatkan hasil tanaman. Kondisi tersebut terjadi apabila kebutuhan nutrisi tanaman tercukupi, sedangkan kandungan nutrisi mol yang digunakan belum sesuai standar. Menurut Badan Standarisasi Nasional (2004) yang menyatakan bahwa standar mutu kandungan unsur hara makro dalam pupuk cair yaitu N,P dan $\mathrm{K}$ mencapai 3-6\%.
Hasil penelitian Tabel 4 menunjukkan bahwa di antara perlakuan frekuensi penyiraman tidak berbeda nyata pada jumlah umbi bawang merah. Hal ini diduga karena berat vegetatif tanaman yang rendah pada setiap frekuensi penyiraman yang mengakibatkan rendahnya bobot segar bawang merah, karena rendahnya jumlah nutrisi yang dibutuhkan saat fase vegetatif tanaman. Hal ini sesuai dengan penelitian Surtinah (2018) yang menyatakan bahwa organ vegetatif tanaman menjadikan salah satu faktor yang berperan dalam menentukan produksi kedelai diantaranya yaitu tinggi tanaman, jumlah daun, luas daun, berat kering tanaman atau berat kering tajuk yang memiliki hubungan yang paling erat terhadap produksi. Selain di pengaruhi oleh nutrisi, lamanya frekuensi peyiraman yang mengakibatkan kelembaban rendah karena suhu udara di dalam rumah kaca yang tinggi memberikan pengaruh terhadap jumlah produksi bawang merah. Hal ini sesuai dengan pendapat Yuliawan (2012) yang menyatakan bahwa kenaikan suhu $1^{\circ} \mathrm{C}$ akan menurunkan produksi sebesar $5-7 \%$.

\section{KESIMPULAN}

Simpulan dari penelitian ini adalah pemberian MOL bonggol pisang pada tanah dapat meningkatkan pertmbuhan dan produksi bawang merah tanpa dipengaruhi frekuensi penyyiraman. Level mol bonggol pisang $40 \mathrm{ml}$ dapat menghasilkan pertumbuhan tinggi tanaman, berat segar vegetatif tanaman dan jumlah umbi bawang 
merah tertinggi. Frekuensi penyiraman tidak mempengaruhi semua parameter dan produksi bawang merah.

Perlu dilakukan penelitian lebih lanjut pada level bonggol pisang yang lebih tinggi untuk menghasilkan level yang optimal pada hasil yang maksimal. Frekuensi penyiraman yang lebih pendek perlu dilakukan penelitian lebih lanjut sehingga dapat meningkatkan efisiensi penyerapan nutrisi tanaman.

\section{DAFTAR PUSTAKA}

Badan Standarisasi Nasional. 2004. Standar Kualitas Kompos. SNI 19-7030-2004

Dharma, P. A. W., Suwastika, A. A. N. G dan N. W. S. Sutari. 2018. Kajian Pemanfaatan Limbah Sabut Kelapa Menjadi larutan Mikroorgansime Lokal. E-Jurnal. Agroekoteknologi Tropika. 7 (2) :200-210.

Djumali dan E. Nurnasari. 2010. Pengaruh kondisi ketinggian tempat terhadap produksi dan mutu tembakau temanggung. Buletin Tanaman Tembakau, Serat dan Minyak Industri. 2 (2) :45-59.

Hatta, M. 2006. Pengaruh Suhu Air Penyiraman Terhadap Pertumbuhan Bibit Cabai (Capsicum annum L.). Agrista. 10 (3) : 136141.

Haq, M. S., M. Fauziah dan Karyudi. 2015. Pengaruh pupuk daun nitrogen dan zink dengan pestisida metomil pada tanaman teh yang terserang hama Empoasca Sp. (1) pengaruh terhadap peningkatan hasil pucuk dan komponen hasil. J. Penelitian Teh dan Kina. 1 (18) : 45-54.

Herlinawati., D. N.Aini dan B. Sugiyanto. 2017. Aplikasi mikroorganisme lokal bonggol pisang dan pupuk kandang kambing terhadap produksi kedelai (Glycine Max (L.) Merrill)) varietas baluran. J. Of Applied Agricultural Sciences. 1 (1) :35-43.

Juliandi dan Rosmaiti. 2016. Peningkatan Pertumbuhan dan Produksi Kacang Tanah
(Arachis hypogaea L.) dengan pertumbuhan Mikroorganisme Lokal (MOL) dan Pembumbunan. Agrosamudra. J. Penelitian. 3 (2) :8-18.

Kementrian Pertanian. 2013. Kinerja Perdagangan Komoditas Pertanian. Kementan Press. 4 (1). Jakarta.

Neliyati., Gusniwati dan B. Irawan. 2007. Penggunaan zat pengatur tum a ${ }^{-}$ksin untuk memacu perakaran dan 1 uhan stek duku. J. Agronomi. 11 (1) : 1 (u- v.

Panudju, T.I. 2011. Pedoman Teknis Pengembangan Rumah Kompos Tahun Anggaran 2011. Direktorat Perluasan dan Pengelolaan Lahan, Direktorat Jendral Prasarana dan Sarana Pertanian Kementerian Pertanian. Jakarta.

Parman, S. 2007. Pengaruh pemberian pupuk organik cair terhadap pertumbuhan dan hasil produksi kentang (Solanum tuberosum L. ). Bul. Anatomi dan Fisiologi. 15 (2) : 21-31.

Pitojo, S. 2003. Benih Bawang Merah. Kanisius, Yogyakarta.

Purwasasmita, M dan K. Kurnia. 2009. Mikroorganisme Lokal sebagai Pemicu Siklus Kehidupan dalam Bioreaktor Tanaman. Seminar Nasional Teknik KimiaIndonesia-SNTKI 2009. Bandung 1920 Oktober 2009.

Rostikawati, R. T., D. N. Sari dan S. Kurniasih. 2012. Pengaruh Pemberian Mikroorganisme Lokal (MOL) Bonggol Pisang Nangka Terhadap Produksi Rosella (Hibiscus sabdariffa L.). Program Studi Pendidikan Biologi Fakultas Keguruan dan Ilmu Pendidikan Universitas Pakuan. Bogor.

Santosa, E. 2008. Peranan Mikroorganisme Lokal dalam Budidaya Tanaman Padi Metode System Of Rice Intensification. Departemen Pertanian, Jakarta.

Setianingsih, R. 2009. Kajian pemanfaatan pupuk 
cair mikroorganisme lokal dalam priming, umur bibit dan peningkatan daya hasil tanaman padi (Oryza sativa L.) (uji coba penerapan system of rice intensification (SRI)). Program pascasarjana Universitas Negeri Sebelas Maret, Surakarta. (Tesis Magister Agronomi).

Siagian, B., R. Saragih dan B. S. J. Damanik. 2014. Pertumbuhan dan Produksi Bawang Merah dengan Pengolahan Tanah yang Berbeda dan Pemberian Pupuk NPK. J. Online Agroekoteknologi. 2 (2) : 712-725.

Sidharta, B. B. R., M. B. B. Ole dan A. W. N. Jati. 2013. Penggunaan Mikroorganisme Bonggol Pisang (Musa paradisiacal) sebagai Dekomposer Bahan Orgnaik. Universitas ATMA Jaya Jogyakarta. Fakultas Teknobiologi. Program Teknobiologi. Yogyakarta.

Sumarni, N dan A. Hidayat. 2005. Panduan Teknis Budidaya Bawang Merah. Balai Penelitian Sayuran. Pusat penelitian dan Pengembangan Pertanian. Badan Penelitian dan Pengembangan Pertanian.

Surtinah. 2018. Korelasi Pertumbuhan Organ Vegetatif Dengan Produksi Kedelai (Glycine $\max$ (L.) Merill)). Fakultas Pertanian. Universitas Lancang Kuning.

Suwandi., N. Sumarni dan R. Rosliani. 2012. Optimasi jarak tanam dan dosis pupuk NPK untuk produksi bawang merah dari benih umbi mini di dataran tinggi. . J. Hort. 22 (2) $: 147-154$.

Syfandy, I. 2017. Pengaruh Ekstrak Limbah Bawang Merah (Allium cepa L.) Terhadap Pertumbuhan Tanaman Sawi (Brassica juncea L.)Secara Hidroponik Sebagai
Penunjang Praktikum Mata Kuliah Fisiologi Tumbuhan. Fakultas Tarbiyah dan Keguruan. Darussalam Banda Aceh.

Waluyo, L. 2004. Mikrobiologi Umum. Penerbit Universitas Muhamadiyah Press, Malang.

Wibowo, S. 2009. Budidaya Bawang. Penebar Swadaya, Jakarta.

Wuryandari, B. B. 2015. Pengaruh Perbedaan Konsentrasi dan Frekuensi Pemberian Mikroorganisme Lokal (MOL) dari Bonggol Pisang (Musa balbisiana) Terhadap Pertumbuhan dan Hasil Produksi Tanaman Tomat (Lycopersicon lycopersicum (L.) Var. Commune) Program Studi Pendidikan Biologi. Fakultas Keguruan dan Ilmu Pendidikan. Universitas Sanata Dharma. Yogyakarta.

Yani, R. B. 2016. Pengaruh $\mathrm{pH}$ dan Suhu Terhadap Produksi Antibiotika dari Isolat Bakteri Endofitik Pada Tumbuhan Andalas (Morus macroura Miq.) Skripsi. Jurusan Biologi. Fakultas Matematika dan Ilmu Pengetahuan Alam. Universitas Andalas.

Yeremia, E. 2016. Pengaruh Konsentrasi Mikroorganisme Lokal (MOL) dari Rebung Bambu Terhadap Pertumbuhan Tanaman Sawi Caisim (Brassica juncea L.). Skripsi. Fakultas Keguruan dan Ilmu Pendidikan. Universitas Sanata Dharma. Yogyakarta.

Yuliawan, T. 2012. Pengaruh Kenaikan Suhu Terhadap Produksi Tanaman padi Sawah Irigasi dan Tadah Hujan di Indonesia Menggunakan Model Simulasi Pertanian Sheirary Rice Berbasiskan Sistem Informasi Geografis (SIG). Skripsi. Fakultas Matematika dan Ilmu Pengetahuan Alam. Institut Pertanian Bogor. Bogor. 